\title{
Senate Moderates in the League of Nations Battle: The Case of Albert B. Cummins
}

\section{Herbert F. Margulies}

IN APRIL 1917, well before the United States entered the First World War, President Woodrow Wilson urged the creation, as part of the ultimate peace settlement, of an international organization to guard against future wars. Later, creation of such an organization became a principal aim of American diplomatic efforts during the war. At war's end, Wilson, as head of the American delegation to the peace conference in Paris, presided over the drafting of a covenant for the League of Nations. The organization would preserve peace in varied ways, including international consultation when war threatened, arbitration to settle warbreeding disputes, and disarmament. Most important of all, in Wilson's view, under the terms of Article Ten of the covenant, members would agree to take collective action, militarily if necessary, against aggression. The very existence of such an agreement among nations, Wilson believed, would lessen the likelihood of future warfare. ${ }^{1}$

Agreement at Paris, gained only after some painful concessions on Wilson's part, both to American senators and to foreign bargainers, was but part of the battle for Wilson, and the easier part, as it turned out. Ahead still, as Wilson sailed for home early in July 1919, lay the struggle for Senate consent to the Versailles

1. The best source on Wilson's thought and action respecting the League is Arthur S. Link, Woodrow Wilson: Revolution, War, and Peace (Arlington Heights, IL, 1979), 72-103.

THE ANNALS OF IOWA 50 (Spring 1990). (C) The State Historical Society of Iowa, 1990. 
Treaty, of which the League Covenant was the most controversial part. Ominously for the League's prospects, Republicans controlled the Senate, forty-nine to forty-seven, and many Republican senators harbored grievances against Wilson and doubts about the covenant. The majority leader and chairman of the Foreign Relations Committee, Henry Cabot Lodge of Massachusetts, shared fully in these doubts. Wilson did not appreciate the magnitude of the opposition, and having made some concessions already, was reluctant to go further.

The battle in the Senate was prolonged, extending from July 10, 1919, when Wilson first presented the treaty, until March 19, 1920, when the Senate, for the second and last time, voted it down. The outcome has been seen by scholars as momentous, so the story of the battle in the Senate has received much attention. By tradition, accounts divide the senators into four categories. The largest group, but still well short of the sixty-four needed to provide a two-thirds majority for treaty approval, consisted of the Wilson Democrats, who were willing to accept the treaty exactly as Wilson presented it. At the opposite extreme were sixteen irreconcilables, two of them Democrats and the rest Republicans, who were against the treaty in any form. They were vocal and influential, but not themselves numerous enough to prevent approval of the treaty. In between, according to the conventional accounts, were two sets of Republicans known as mild reservationists and strong reservationists, each of which urged the adoption of reservations that would state America's understanding of certain covenant provisions, and in so doing protect the United States from unwanted obligations. The strong reservationists, followers of Lodge, in addition to insisting on more stringent reservations than appealed to the mild reservationists, also favored some amendments to the treaty that would alter the text and thus change the treaty for all the signatories.

Elsewhere, I have contended that there were eight Republican senators whose views and actions place them in none of the conventional four categories, but rather in a position midway between the mild and strong reservationists. The eight were Albert Cummins and William Kenyon of Iowa, Charles Townsend of Michigan, Selden Spencer of Missouri, Reed Smoot of Utah, Wesley Jones of Washington, Arthur Capper of Kansas, and 
George McLean of Connecticut. I have suggested that these senators be called "moderates."

It is not surprising that the moderates have been overlooked, for they did not caucus together nor did they respond to any internal leadership. They did not always vote as one, and they did not agree on all points. They did, however, have enough in common, and enough that differentiated them from both the mild and strong reservationists, to warrant separate classification. The point is more than a quibble, for the moderates held strategic ground with respect to voting and calculations of strategy. The mild reservationists were but ten in number, and even in combination with the Wilson Democrats they could not have created a two-thirds majority for treaty approval. Joined by the moderates, however, they could have come within a vote or two of creating such a majority, and any such combination would have put extreme pressure on Lodge and his followers. Study of some of the individual moderates may help to establish the fact of their separateness. ${ }^{3}$

In the case of Albert B. Cummins of Iowa, the subject of this article, such study can do more. Cummins took a prominent role in the League contest. One may achieve deeper understanding of that battle by gaining greater knowledge and insight respecting the senator's thought and action.

FROM THE FIRST, President Wilson had believed that popular support for the League would be sufficient to win the votes of senators. When, in September 1919, he found himself stymied in Washington, Wilson acted on his assumption by launching a speaking tour on behalf of the League. One of his early stops was Iowa.

In some respects, Iowa might have seemed lacking in promise, for in common with other states of the Middle West it had a

2. Herbert F. Margulies, The Mild Reservationists and the League of Nations Controversy in the Senate (Columbia, MO, 1989). Due to limitations of space, I was not able to give detailed attention to the moderates.

3. See Herbert F. Margulies, "Senate Moderates in the League of Nations Battle: The Case of Selden P. Spencer," Missouri Historical Review 83 (July 1989), 373-94; and idem, "Senate Moderates in the League of Nations Battle: The Case of William S. Kenyon," Midwest Review, forthcoming. 
tradition of isolationism. ${ }^{4}$ Judged by press statements, polls, and votes in Congress from 1914 through 1917, the Middle West, more than other sections, favored an arms embargo, resisted preparedness measures, and, to lessen the chance of military involvement, would have sacrificed the right of Americans to travel on belligerent ships and other rights of neutrals. Of the fifty-two representatives who voted against declaring war, thirty-two came from the Middle West. Iowa shared fully in the establishment of this record. The lowa delegation in the House of Representatives, for example, was unanimous in favor of the McLemore resolution to ban Americans from sailing on belligerent vessels. ${ }^{5}$

The thinking of middle westerners generally and lowans in particular may be attributed to a combination of factors. One was an agrarian-based progressivism that was suspicious of eastern special interests, in international as in domestic affairs, and that saw foreign entanglements as inimical to domestic reform. Southerners shared such views, but tempered them in the Wilson years in the interests of the Democratic party, while the predominantly Republican Middle West, including Iowa, was spurred by partisanship to vent isolationist predispositions. The relatively large concentration of German-Americans and ScandinavianAmericans in Iowa and throughout the Middle West augmented the tendency. The German-Americans hoped to avoid conflict with their country of origin, while Scandinavian-Americans brought with them some cynicism about European conflicts, some pacifism, and a concern for protection of American democracy against the threat of militarism. ${ }^{6}$

Notwithstanding this record, Wilson had good grounds to

4. Some historians have questioned the extent and timing of middle western isolationism. See, for example, Warren Kuehl, "Midwestern Newspapers and lsolationist Sentiment," Diplomatic History 3 (Summer 1979), 283-306; and William G. Carleton, "Isolationism and the Middle West," Mississippi Valley Historical Review 33 (December 1946), 377-90. The dispute, however, does not turn on the years immediately preceding American entry into World War I.

5. Ray A. Billington, "The Origins of Middle Western Isolationism," Political Science Quarterly 60 (March 1945), 54-56; John Milton Cooper, Jr., The Vanity of Power: American Isolationism and World War I, 1914-1917 (Westport, CT, 1969), 25, 179-80, 203, 115.

6. Wayne S. Cole, "Gerald P. Nye and Agrarian Bases for the Rise and Fall of American Isolationism," in Three Faces of Midwestern Isolationism, ed. John N. Schacht (Iowa City, 1981), 3-4; Cooper, Vanity of Power, 26-27, 204, 224; Billington, "Origins of Middle Western Isolationism," 50-53. 
hope for support of the League among Iowans. Isolationism had several variants, and the predominant form in lowa and the Middle West generally was not ultranationalism but rather idealistic isolationism. Closely related to progressivism domestically, and to the much older notion of a special American mission, idealistic isolationism stressed America's obligation to demonstrate to the world a better way of life. But many devotees of this approach were open also to Wilson's idealistic wartime appeal to advance the cause of world peace, again in accordance with progressive principles and the faith in an American mission. For many lowans, idealistic isolationism was transformed into idealistic internationalism. ${ }^{7}$

Newspapers in Iowa, as elsewhere in the Middle West, were predominantly pro-League in the spring of 1919 and during the months that followed. Most important of these in lowa was the Des Moines Register, which sold more than one hundred thousand copies per day statewide, more than any other two lowa papers combined. The Sioux City Tribune, like the Register a Republican paper, also lent consistent and important support for the League. Iowa churches also contributed to interest in and support for the League. Thus, when Wilson came to Des Moines to speak, he received an enthusiastic reception at the station, in a parade to the auditorium, and in the course of his speech, which had to be relayed to the overflow crowd outside. Reporters traveling with Wilson contrasted his warm reception in lowa with a certain coolness at the start of the tour in Ohio. By contrast, irreconcilables Hiram Johnson and William Borah, traveling separately along Wilson's trail, evoked much less interest or enthusiasm from Iowans. Afterwards, in a letter to a constituent and in a Senate speech, Iowa Senator William Kenyon, though critical of the covenant and of Wilson, acknowledged that a majority of Iowans favored the League charter as it was. ${ }^{8}$

7. On idealistic isolationism, see Cooper, Vanity of Power, 12, 94, 8; and idem, "Progressivism and American Foreign Policy: A Reconsideration," MidAmerica 51 (1969), 274.

8. Billington, "Origins of Middle Western Isolationism," 56; Kuehl, "Midwestern Newspapers and Isolationist Sentiment," 287; David Henry Jennings, "President Wilson's Tour in September 1919: A Study of the Forces Operating during the League of Nations Fight" (Ph.D. diss., Ohio State University, 1958), 116, 122-25; Congressional Record, 66th Cong., 1st sess. (hereafter cited as CR 66:1), 5149-55, 10 September 1919. 
ALBERT CUMMINS, like Kenyon, was not at one with many of his constituents on this issue, but he shared with them a background of progressivism. Sixty-nine years old and well respected in the Senate, Cummins was a self-made man who had worked his way through a small college in Pennsylvania in two years, then achieved early prominence at the Iowa bar in a prolonged and successful challenge to the barbed-wire trust. In politics, Cummins took the lead among progressive Republicans in his state, and as their champion became governor in 1902. Entering the Senate in November 1908, Cummins immediately took a leading place among insurgent Republicans who dramatically attacked their party's Payne-Aldrich tariff bill. In 1912, when Theodore Roosevelt led many progressive Republicans into a new party, Cummins, like many other middle western officeholders, supported Roosevelt's candidacy but refused to leave the Republican party. In the years that followed, Cummins became somewhat more conservative, while retaining a progressive identification. By 1919 he was on good terms with many of his former enemies, in Iowa and in the Senate. He remained true to his insurgent origins, however, in persistently championing democratic practices, and in this connection he was constantly critical of President Wilson's dictatorial tendencies and his overreliance on the Democratic party. 9

With Iowans generally, Cummins had taken an isolationist position prior to America's entry into the World War. On a number of issues, including a treaty with Nicaragua and the possibility of granting independence to the Philippines, Cummins took a moderate antiimperialist stand. ${ }^{10}$ When the issue of preparedness arose in connection with the war in Europe, Cummins continued to oppose enlarging the navy, although he was not as extreme in his opposition as Wisconsin's Robert La Follette and a few others. He was deeply committed to preventing American entanglement in the war, so he supported an arms embargo, a ban on Americans sailing on belligerent ships, and the arming of American mer-

9. Dictionary of American Biography, s.v. "Albert Baird Cummins"; Ralph Mills Sayre, "Albert Baird Cummins and the Progressive Movement in Iowa" (Ph.D. diss., Columbia University, 1958).

10. Barton J. Bernstein and Franklin A. Leib, "Progressive Republican Senators and American Imperialism, 1898-1916: A Reappraisal," Mid-America 50 (July 1968), 198-200. 
chant vessels. But he was not one of the six senators to vote against the declaration of war. ${ }^{11}$

Starting in 1915, Cummins began to preview the ideas he would later espouse when the League Covenant was embodied in the Treaty of Versailles. Evidently abreast of developments in the American peace movement, in 1915 he published an article in which he wrote that America's "paramount duty is to make all things ready for an advance in the cause of international peace." What he had in mind was improved machinery for arbitration, mediation, and delay when international disputes arose. What he did not have in mind was a system of collective security, as he made clear in the Senate after Wilson advanced his League of $\mathrm{Na}-$ tions idea in his "peace without victory" speech of January 22, 1917.12

Following American entry into the war, Cummins became strongly antagonistic to Germany. As the end of the war approached, he stressed imposing a Carthaginian peace on the Germans as the prime immediate object. Nothing should delay that. "Let us forget . . . the League of Nations, which is to rule the earth in accordance with the Sermon on the Mount and in which the United States is to become a mere municipality." After Wilson named a delegation headed by himself and including no Republican leaders, Cummins introduced a resolution to send a group of senators to Paris as observers. ${ }^{13}$

Wilson's ideas soon took concrete form. In February 1919 he returned for a brief stay in the United States to present a completed covenant, albeit one that was still open to revision. Cummins took the opportunity to expound his ideas in the Senate. In so doing, he began on the long and tortuous course that would establish him as a moderate, siding now with the mild reservationists, now with the strong reservationists, but not consistently a member of either faction.

11. Ibid., 178; Cooper, Vanity of Power, 30, 113, 181-82, 199, 221-22; Howard W. Allen, "Republican Reformers and Foreign Policy, 1913-1917," MidAmerica 44 (October 1962), 226-28.

12. Albert B. Cummins, "Defense and Revenue in the Next Congress," Review of Reviews 52 (November 1915), 555; CR 64:2, 2231-35, January 1917, cited in Cooper, Vanity of Power, 149, 150.

13. New York Times, 15 October, 1, 3, 6 December 1918, cited in James Oliver Robertson, No Third Choice: Progressives in Republican Politics, 1916-1921 (New York, 1983), 104. 
THE TONE of Cummins's speech of February 26 was negative. ${ }^{14}$ That may have been due, in part at least, to the speech's context. Hardly anyone then thought or talked about rejecting the League Covenant. Chiefly at issue was whether it should be accepted as presented or modified, and also whether or not action on the covenant should continue or be deferred pending agreement on the more conventional aspects of the treaty.

From the start, Cummins stressed criticisms of the covenant. Quoting Wilson's speech in Boston, he concluded that the president's purpose was to commit the United States not only to help create new nations in southern and eastern Europe, but to protect them as well. This he deplored, calling the covenant "a constitution for the guardianship on the part of the United States of the weaker nations of Europe. It is not a league for the prevention of war. It is a league for invitation to war." Cummins did, however, support protection for France and other nations against Germany, "this enemy of mankind." He also approved of international cooperation against war, but he felt that the parties should agree to terms for peace before attempting to establish a world organization.

The senator feared that there was more bad than good in the covenant Wilson presented. He hoped the bad features would be removed in Paris before the treaty was completed. He offered qualified praise for certain parts of the covenant: he believed that justiciable disputes should be settled by arbitration or adjudication; and that with respect to other issues relating to the existence and welfare of a nation, no war should be undertaken pending consideration by an international body. But he favored no award or judgment, nor any sanction other than opinion. Those who would not follow these procedures should be ostracized. He placed hope in disarmament, too, but thought that could best be accomplished in the treaty itself.

Cummins went on to condemn certain portions of the covenant that he thought outweighed the value of the good parts. The worst provision, for Cummins, was Article Ten, under which the League Council could recommend military action in instances of aggression against a member state. Cummins called it "the most

14. The following summary of the speech is based on the record of it in $C R 65: 3$, 4309-16, 26 February 1919. 
destructive, unjust and reactionary proposal which was ever submitted to a patriotic and intelligent people. ... We are solemnly asked to guarantee that the boundaries of nations, as they now exist or as they will exist when the peace conference has redrawn the map of Europe, Asia, Africa, and Oceania, shall remain without change forever." Cummins warned that mandate provisions might require the United States to oversee the Turkish Empire; that Japan might get an award from the council; and that the League might interfere with American tariff policy. Generally, the senator feared the creation of a world nation that would eclipse the powers of the member states. This, he thought, was Wilson's purpose. Cummins, lauding America's achievements, insisted that it continue as its own master.

The speech pointed towards Cummins's future stance on the League. Seeing some good in it, he would not join the irreconcilables and refuse to approve it under any circumstances. But because of the very serious flaws that he perceived, he would insist on substantial changes limiting American obligations, either by amendments to the text of the covenant or, at the very least, by reservations attached to the resolution of ratification.

FEELING AS HE DID, Cummins willingly cooperated with Republican leader Lodge on what came to be called the Round Robin. On March 3, as the session neared its end the following day, Lodge circulated a resolution criticizing the covenant and asking that its completion be delayed until after the peace settlement with Germany was concluded. When Cummins was consulted, he suggested general verbal changes, which Lodge accepted, and then the lowan signed the document. Democrats blocked consideration of the resolution, but Lodge accomplished his purpose by presenting it and the names of thirty-seven senators or senators-elect who subscribed to it. ${ }^{15}$ The Round Robin put Wilson on notice that to secure Senate approval for the covenant he would have to bring about some changes. There was ample opportunity for the president to do that, so in helping the Round Robin, Cummins did not commit himself irrevocably against the League.

15. Henry Cabot Lodge, The Senate and the League of Nations (New York, 1925), 118-19. 
At Paris in March and April Wilson did, in fact, effect some changes in the covenant. In regard to several issues, including the right of withdrawal, the Monroe Doctrine, and the determination of domestic questions such as tariffs and immigration, the changes afforded fuller protection from League interference in American affairs. Despite the changes, however, Cummins still withheld unqualified endorsement of the covenant. Early in April he had informed a pro-League constituent that the changes he proposed were milder than those recommended by Elihu Root, the prestigious Republican elder statesman. After publication of the revised covenant, however, he told the City Club in St. Louis, "I am not willing to become a citizen of the world in lieu of being a citizen of the United States, neither am I willing that the seat of government should be removed from Washington to Geneva. When the peace terms are concluded, Middle Europe will be divided into fifteen sovereignties. I think a world covenant designed to guarantee the political integrity of these nations will provoke war instead of quelling it." In Des Moines on May 2 he predicted turbulence in southeastern Europe for twenty-five years, and expressed doubt that the United States should stand behind all of the new nations of the area. "I am not sure that they should continue to exist," he said. "It would be usurping the powers of the Almighty to say that we would do this. Who can tell now what situation will prevail twenty years hence?" The fight in the Senate, Cummins predicted, would come on Article Ten, which he called "morally wrong." He thought that the Senate might reserve to the United States the privilege of determining whether it would set a time limit for the operation of the article, after which it would cease to exist. In a statement issued a week later, Cummins favored separating the League and the treaty. He gave qualified approval for the recent changes respecting the Monroe Doctrine and domestic questions and the mandate provision, but he called Article Ten "just as objectionable as ever."16

On May 7 newspapers summarized the terms that the victorious powers would present to Germany. Since the League Covenant would be part of the larger Treaty of Versailles, senatorial

16. Ibid.; Minneapolis Tribune, 2, 11 May 1919; The World (New York), 3 May 1919; New York Times, 11 May 1919. 
reaction to the terms of the treaty affected the fate of the covenant in the United States. Cummins was one of several senators who criticized the provisions under which German economic and political rights in the Shantung peninsula of China would go to Japan instead of reverting to China. But with many other senators, he approved the harsh treatment of Germany. ${ }^{17}$

In June, as treaty negotiations in Europe neared completion, Philander Knox of Pennsylvania introduced in the Senate an updated version of a resolution he had offered in December. In harsh anti-League terms Knox's resolution proposed to separate the League question from the rest of the treaty and to deal with it later. ${ }^{18}$ In immediate response Frederick Hale of Maine and Frank Kellogg of Minnesota invited the scholar-politician Nicholas Murray Butler, president of Columbia University, to come to Washington to discuss the treaty with concerned senators. Cummins was one of a group of about eighteen senators, most of whom were later mild reservationists or moderates, who met with Butler. For our purposes, what the senators told Butler is more important than what Butler told the senators. They said the Republican party should not project a negative image respecting the League, but since Wilson had done nothing to modify Article Ten and since the changes he had brought about regarding the Monroe Doctrine and domestic questions such as the tariff and immigration were inadequate, there must be reservations on those provisions. Also, if the Knox resolution came to a vote, they wanted to add something positive to it. What Cummins contributed to the discussion cannot be known; however, the next day he declared that he would probably offer "affirmative amendments" to the Knox resolution. That proved unnecessary, for Knox and Lodge quietly abandoned the resolution in the face of mounting Republican opposition to it. ${ }^{19}$

17. Des Moines Register, 9 May 1919; Minneapolis Tribune, 9 May 1919; The World (New York), 8 May 1919; New York Times, 11 May 1919.

18. CR 66:1, 894, 10 June 1919.

19. Kellogg to Butler, 19 November 1925, Frank B. Kellogg Papers, Minnesota Historical Society, St. Paul; Nicholas Murray Butler, Across the Busy Years: Recollections and Reflections, 2 vols. (New York, 1939-1940), 2:197; Butler to Frederick Hale, 12 June 1919, Nicholas Murray Butler Papers, Columbia University, New York; The World (New York), 13 June 1919. 
THE TREATY was signed in Europe on June 28, and Wilson sailed for home to present it to the Senate. By then Republicans had found a common denominator to unite them at least temporarily. They agreed to propose reservations to the treaty that would affect only the role of the United States in the League, not the relationship of other members to one another, and thus would not require time-consuming renegotiation.

Senators were concerned not only about delaying the peace process by making renegotiation necessary; they were also concerned that a lengthy Senate debate would divert attention from pressing domestic issues. That concern was greatest among those senators who became mild reservationists and moderates, and it was the driving force behind Cummins's actions during the summer of 1919, although to a lesser extent he probably considered the party's image. Cummins may also have been motivated in part by concern for reelection in 1920 . He faced the prospect of opposition in the primaries from former governor George $W$. Clarke, who headed the League to Enforce Peace in Iowa, which spearheaded pro-League activity. The Des Moines Register had hinted that it might support Clarke. ${ }^{20}$ It would be advantageous to Cummins if the Senate would expeditiously finish with the treaty so it would not be an issue in the election.

Late in September Cummins was still urging haste. "We ought to be free as quickly as possible to turn our thought to some solution of the problems in our domestic affairs, which are the gravest which ever challenged the minds and hearts of humanity," he told the Senate. ${ }^{21}$ Strikes and living costs had peaked in 1919. Class and race feeling were intense. The railroad system, so essential to American life, required reorganization through national legislation after wartime government operation. The problems of farmers and ex-soldiers also required legislative attention. As early as July Cummins appeared anxious to clear the legislative deck for domestic legislation.

He had special reason for concern on this score. As chairman of the Interstate Commerce Committee, he would fashion a bill, ultimately the Esch-Cummins Bill, for the reorganization of the

20. Des Moines Register, 9 June, 15, 31 March 1919. Another possible challenger was Smith Brookhart.

21. CR 66:1, 5957, 26 September 1919. 
American railroad system. The bill would require a great deal of time in the Senate, time that was precious since the nationalized railroad property was to be restored to the companies on January 1,1920 . The League issue competed with railroad legislation for Senate time.

The senator's first important concrete action to hasten matters came on July 8 , two days before Wilson presented the treaty to the Senate. Accompanied by Irvine Lenroot of Wisconsin, Cummins called on Lodge. Lenroot and Cummins proposed that Lodge take the lead in formulating a Republican program of reservations to be brought to the floor immediately in lieu of long hearings in the Foreign Relations Committee. Lenroot and Cummins wanted to challenge the Democrats to ratify the treaty immediately or take the blame for opposing a reasonable compromise and obstructing economic recovery. The senators felt that Republicans, with the possible exception of Porter McCumber of North Dakota, could agree on such a program within ten days, and enough Democrats would join to produce a working majority. 22

Lodge did not act on the advice of Cummins and Lenroot, but instead undertook leisurely consideration of the treaty in committee. Meanwhile, between July 17 and August 1, Wilson held separate interviews with twenty-three Republican senators, those deemed most promising for his cause. The president resisted reservations, especially within the ratification resolution, and he hoped to persuade his guests that they were not necessary. Cummins was one of those he invited. Like most of the others, the lowan afterwards said that he had not changed his mind. ${ }^{23}$

Cummins remained concerned about prompt ratification, and at this time he asked for no more than reservations. To advance the cause, on July 30 and 31 he participated in two long meetings with six other Republicans: Lenroot, Kellogg, McCumber, Charles McNary of Oregon, LeBaron Colt of Rhode Island, and Selden Spencer of Missouri. All of these but Spencer emerged

22. Frank Kellogg to Lodge, 7 July 1919, Henry Cabot Lodge Papers, Massachusetts State Historical Society, Boston; Minneapolis Tribune, 9 July 1919; The World (New York), 9, 10 July 1919.

23. Boston Herald, 22 July 1919. 
as mild reservationist leaders in the months that followed. Already, the term mild reservationist was coming into use and being applied to the group of seven. ${ }^{24} \mathrm{Had}$ that group achieved prompt success and brought the conflict to an end in August, Cummins would have to be seen as a mild reservationist rather than as a moderate.

The meeting had Lodge's blessings. Although Lodge differed with the group on some matters, he continued to seek party agreement on a specific program. If that could be accomplished, he knew, there would be no danger that pro-League Republicans would help the Democrats create a majority for approval without reservations, a situation that would make his party appear to be unduly obstructing the legislative process. ${ }^{25}$ Lodge's support enhanced the importance of the effort.

The senators agreed to prepare reservations on four topics that had been talked about for many months: Article Ten, the Monroe Doctrine, domestic questions, and withdrawal. Criticisms of the Shantung provisions of the treaty were set aside because Wilson had held out the hope that the matter might be dealt with through diplomacy. The task was difficult, for the seven were not like-minded. They had trouble, especially, agreeing on a reservation to Article Ten. Cummins, least mild of the lot, advocated striking out the article altogether, as Elihu Root had proposed in June. Finally, however, he acquiesced in a reservation that made clear Congress's constitutional right to declare war. By later standards, the proposal was mild. So too were the other three reservations on which the group reached agreement. Their settlement remained tentative respecting Article Ten, and they all understood that the proposals would simply be points of departure in negotiations with other senators. ${ }^{26}$

Negotiations among Republicans and between Republicans and Democrats proved sufficiently serious to cause Gilbert Hitch-

24. McCumber to William Howard Taft, 31 July 1919, William Howard Taft Papers, Library of Congress; Minneapolis Tribune, 1 August 1919; The World (New York), 8 August 1919.

25. The World (New York), 17 July 1919; Lodge to Louis A. Coolidge, 2 August 1919, Lodge Papers.

26. New York Times, 5 August 1919; CR 66:1, 5959, 26 September 1919; The World (New York), 3, 5 August 1919; New York Times, 4, 5 August 1919. For the text of the proposals, see $C R 66: 1,3690,7$ August 1919. 
cock of Nebraska, acting leader for the Democrats and ranking member of the Foreign Relations Committee, to call on Wilson for advice. The president was not encouraging. He continued to oppose reservations, especially if they were embodied in the resolution of ratification, as the Republicans insisted. He did not want to go back on his word to British and French leaders, to whom he had given assurances of Senate approval. Nor did he want Europeans to think the United States was joining the League halfheartedly. He also feared that such reservations might encourage counterproposals from other nations. Finally, he distrusted Republicans such as Lodge, suspecting that any show of willingness to accept mild reservations would beget demands for harsher ones. ${ }^{27}$

Wilson had in mind an alternative course which, if successful, would preclude the need for concessions. He would go over the heads of senators and take his case to the people in an extended speaking campaign. A White House meeting with the Foreign Relations Committee on August 19 served as a prelude to the campaign, for a transcript was made immediately available to newspapers. On September 4 the president began his tour in Columbus, Ohio. His gamble failed, and in retrospect it seemed that the best opportunity for ratification had come and gone in August.

REBUFFED in his effort to achieve speedy ratification, Cummins increasingly acted in accordance with his convictions about the deficiencies in the covenant. He was perhaps encouraged in this by the lessening popularity of the League in the country and in the Senate. Another factor was the Democrats' failure to renew compromise discussions. Initially, Democratic leaders awaited the results of Wilson's tour; after that, they had no access to him, for on October 2 he suffered a severe stroke and for months thereafter was inaccessible.

In late August the Foreign Relations Committee approved a number of outright amendments to the treaty. The one that

27. Sondra R. Herman, Eleven Against War: Studies in American Internationalist Thought, 1898-1921 (Stanford, CA, 1969), 207-8; Thomas A. Bailey, Woodrow Wilson and the Lost Peace (New York, 1944), 184; William G. McAdoo, Crowded Years: The Reminiscences of William G. McAdoo (Boston, 1931), 514. 
initially attracted the most attention set out to make the Shantung provisions of the treaty more favorable to China. Fearing prolonged renegotiation of the treaty, and perhaps worse - the Allies had committed themselves to Japan's claims during the war - on August 30 four members of the group of seven (McCumber, Colt, McNary, and Kellogg), joined now by Knute Nelson of Minnesota, met to plot a course of opposition to that amendment and others. Cummins reportedly adhered to the group's program two days later, but in fact he did not, nor did he again act together with those who were emerging as the principal mild reservationists. ${ }^{28}$

The Foreign Relations Committee also approved a reservation to Article Ten that was much tougher than the one proposed by the group of seven. Cummins soon announced his support for the committee's reservation to Article Ten, as well as its reservations on the three other conventional topics, and said that he was preparing a speech that he would give as soon as possible. Cummins delivered the promised speech on September 26. On the same day President Wilson spoke in Des Moines, calling on Cummins and Kenyon to support the treaty without reservations. Cummins's speech thus represented both the beginning of a trend toward distancing himself from the mild reservationists, and, because of its timing, an effectual defiance of the president. ${ }^{29}$

The Senate veteran expressed shock at some of the language Wilson had used in characterizing senators. Threats and epithets such as "contemptible quitters" would do him no good in the Senate, Cummins said. He went on to reiterate the position of limited internationalism that he had expressed in February. The war, he said, had not been fought to make the world safe for democracy, but to defend America's interest and honor by crushing Germany and forever eliminating her as a military menace. The nation's duty was to join the Allies in that postwar purpose, but not "in every undertaking which they may think necessary in order to

28. New York Times, 1 September 1919; St. Louis Post-Dispatch, 3 September 1919.

29. Des Moines Register, 7 September 1919; Ray S. Baker and William E. Dodd, eds., The Public Papers of Woodrow Wilson: War and Peace, Presidential Messages, Addresses and Public Papers (1917-1924), 6 vols. (New York, 1927), $6: 26-27$. The following summary of Cummins's speech is based on the record of it in CR 66:1, 5952-57, 26 September 1919. 
compose Europe. . . . Our duty is limited to Germany and her future; their duty expands into whatever concerns their relations with the nations of that continent."

With regard to the covenant, his views were much as they had been in February. He continued to approve provisions for arbitration of international disputes, discussion of war-threatening situations in the League Council, delay in making war, elaboration of international law, and disarmament. But other things, in particular Article Ten, seemed so dangerous that unless the situation were rectified, he would vote against ratification. "In all my life," Cummins said, "I have never seen good and evil so closely associated and upon such intimate terms as they are in the instrument before us."

In February he had raised objections respecting domestic questions, the Monroe Doctrine, Article Ten, and mandates. In the main, the last of these had been dealt with by the peacemakers, and only a minor reservation was needed. Efforts to cope with the domestic questions and the Monroe Doctrine problems had failed. Presumably, the committee's reservations would meet the need. Article Ten had not been altered, however, and remained the great evil in the covenant, in Cummins's view. "I do not believe that the welfare of humanity will be promoted by a compact through which a few strong nations will dominate and control many weaker nations," he said. "The protection which Article Ten is designed to furnish to feeble powers must inevitably lead either to their complete subjection or to continuous revolution." For the United States to join with two or three other powers to "undertake the guardianship of the world" would require a large military force and a great expenditure of money. Further, to "keep these restless, warring, half-civilized people in peace with each other" seemed impossible. The attempt would only bring the great powers into conflict. Moreover, enforcement of present boundaries, in the face of changing conditions, was unjust. "There are times when wars of conquest are right," he insisted. "Does not the United States exist by virtue of conquest?" In further condemnation of Article Ten, Cummins suggested that it exceeded the constitutional limits to the treaty power. Certainly he would vote for the committee reservation to Article Ten. But he would like to go further and "write into the resolution of ratification the plain, simple statement that the United States assumes 
no obligation whatsoever under Article Ten."

In connection with those very tough views on Article Ten, Cummins criticized reporters who, without interviewing him, had called him a mild reservationist. Further disassociating himself from the mild reservationists, the Iowan commented on the so-called "six vote" question. Assuming that the British Empire would have six votes in the League Assembly because Canada, Australia, New Zealand, South Africa, and India presumably would always vote with Great Britain, Hiram Johnson proposed an amendment that would give the United States a like number of votes. The issue was being hotly debated in the Senate and the country. Although Cummins did not feel that the covenant's voting provisions posed much danger, he agreed that they did constitute a grave injustice. Thus, he implied his support for the amendment, which the mild reservationist leaders hoped to defeat. But he would not vote for the Shantung amendment, he said, for it constituted the very sort of meddling that he deplored.

Cummins also continued to want to hasten the process of peacemaking. He did not share the opinion that ratification would quiet unrest abroad. Rather, his concern for haste was "based on the profound conviction that we ought to be free as quickly as possible to turn our thoughts to some solution of the problems in our domestic affairs, which are the gravest which ever challenged the minds and hearts of humanity." These comments on the Shantung amendment and the need for haste thus differentiated Cummins not only from irreconcilables but from strong reservationists. He staked out a position between the latter and the mild reservationists.

AS MATTERS DEVELOPED, Hiram Johnson's amendment was given low priority. The first committee amendments voted on in the Senate were those authored by Albert Fall of New Mexico. Thirty-seven in number, they would keep the United States off of various commissions established under the treaty. Mild reservationist leader Irvine Lenroot assured his colleagues that one or several reservations asserting Congress's rights in such matters could and would meet the situation. That course, argued Walter Edge of New Jersey, would be more expeditious than amend- 
ments, and would permit the Senate to act on other matters. ${ }^{30}$

The first vote was generally seen as the key one. The proposed amendment would bar American participation on a commission to determine the boundaries between Belgium and Germany. Cummins joined sixteen other Republicans and most of the Democrats to defeat it, 58-30. The seventeen Republicans were, according to the New York Times, the senators who in August had been willing to ratify the covenant with the reservations offered by the group of seven. ${ }^{31}$

Most of the other Fall amendments were rejected en bloc, without a roll call. But some further roll calls were taken. The coalition that defeated the first amendment held well enough on the rest to defeat them all, but occasionally one of the opposition Republicans switched and voted for an amendment. Cummins was one of five such Republicans to vote for an amendment relating to a plebiscite and a governing commission for Upper Silesia. The United States had just sent two regiments there to help to bring order. The amendment lost, 31-46. When the Shantung amendment came to a vote on October 16, Cummins was one of fourteen Republicans to vote with the Democrats to defeat it, 35-55. But on the Johnson amendment, he separated himself from nine mild reservationists and voted in favor. The amendment lost, nevertheless, 38-40. Political ties with Johnson, an active presidential aspirant, may have influenced Cummins. Two days later, October 29, the Senate acted on four amendments, and between November 4 and 6 it completed action on amendments with three more votes. In those votes, Cummins's convictions outweighed his concern for expedition, as he sided with strong reservationists and irreconcilables more frequently than with mild reservationists. ${ }^{32}$

The amendments disposed of, the Senate turned to a new and expanded list of reservations from the Foreign Relations

30. Ibid., 6265-66, 6379, 2 October 1919; 6130-32, 30 September 1919.

31. Ibid., 6269, 2 October 1919; New York Times, 3 October 1919. There had been eighteen such Republicans in August, but one of them, George McLean, defected on the Fall amendments.

32. CR 66:1, 6279-80, 2 October 1919; 7013, 16 October 1919; 7548, 27 October 1919; 7679-80, 7692, 29 October 1919; 7942, 4 November 1919; 7969, 5 November 1919. 
Committee, and proposals from individual senators. In the main, the Republicans agreed with the committee's proposals. But agreements were neither complete nor formal, so there was some contention. In a few instances, Cummins had occasion to continue on the tougher course he had been taking.

When the so-called preamble came up on November 7, irreconcilable William Borah offered an amendment that would require acceptance of American reservations not by three of the four great powers, as the committee proposed, but by all four. The amendment, if adopted, would have seriously jeopardized the prospect of the United States joining the League, for it would have been hard for Japan to accept the Shantung reservation. The Senate rejected Borah's amendment 63-25, but Cummins supported it. ${ }^{33}$

The committee's new withdrawal reservation was in some respects tougher than the September version. Like the earlier version, the new reservation affirmed the right to withdraw from the League. It also specified, however, that withdrawal be enacted not by joint resolution but by concurrent resolution, which would not require the president's signature. Knute Nelson offered an amendment to substitute "joint" for "concurrent." Although he was a partisan Republican, the Civil War veteran, in an emotional speech, argued against putting "a slight upon the President of the United States." Cummins responded in a way that might have reminded listeners of his background as a leader among insurgent Republicans during the Taft presidency. "The whole history of the United States," Cummins said, "is one continued encroachment of the executive branch upon the legislative branch." In recent years, under Wilson, that tendency had accelerated. The root of the problem, he felt, was the president's appointive power. The treaty would make the presidency still stronger by creating new appointive positions. Cummins asserted that he was expressing not a partisan or anti-Wilson view, but one to which he had consistently adhered. He had been more critical of a $\operatorname{Re}-$ publican president, he said, than of Wilson. The Senate subsequently rejected Nelson's amendment, 39-45. ${ }^{34}$

33. Ibid., 8069, 7 November 1919.

34. Ibid., 8135-37, 8 November 1919. 
Next came the reservation to Article Ten. Debate had begun four days earlier, and Cummins had gotten into it. Borah said that at the appropriate time he would offer an amendment to the reservation; his amendment would strike the article altogether. Cummins agreed with Borah that the committee's reservation, worked out in September in long negotiations between Lodge and mild reservationists, was not strong enough. He wanted a clearer renunciation of all military obligation under the article. However, he would not support Borah's amendment, he said, because he was willing that other nations should have the use of the article for their relations with one another. Lodge may have considered strengthening the reservation, principally to satisfy Cummins and Senator Wesley Jones of Washington. If so, he soon abandoned the idea. As the Senate began to consider the reservation, Borah offered a substitute: "The United States assumes no obligation, legal or moral, under article 10 and shall not be bound by any of the terms or conditions of said article." The motion lost, 18-68, but Cummins supported it. He took a tough stand, too, in supporting several reservations proposed not by the committee but by individuals. None of them passed. ${ }^{35}$

On November 19 the Senate debated Lodge's resolution of ratification, and then voted. Following the wishes expressed by Wilson in a letter to them, the Democrats opposed the resolution, and, with the irreconcilables, caused its defeat, 39-55. Eighteen Republicans supported a motion to reconsider, and thus give the Democrats a second chance to vote for the Lodge resolution, or, as the Democrats hoped, to force a compromise. Only Cummins, of the mild reservationists and moderates, opposed the motion, which carried, 63-30. ${ }^{36}$ Nothing came of this second opportunity, however. To some, it seemed that the long battle was over and that the United States would make a separate peace.

DESPITE THE HARD LINE Cummins had taken on amendments and reservations, he was not among those who were content to abandon the treaty. Instead, he resumed the active and positive

35. Ibid., 7946, 4 November 1919; 8212, 10 November 1919; 8642-44, 17 November 1919; 8744-46, 18 November 1919; New York Tribune, 6 November 1919.

36. Ibid., 8786-87, 19 November 1919. 
role he had played in July and August as a member of the group of seven. This he could do with no sacrifice of consistency, for until February 1920 the treaty and covenant were not again before the Senate. Thus, Cummins had less occasion to focus on fancied flaws, and more opportunity to concentrate on the more general goal of ratification.

In the days that followed the Senate's November 19 vote, Gilbert Hitchcock, acting leader for the Democrats and ranking member of the Foreign Relations Committee, canvassed Republican senators. On November 24 he informed Wilson of his findings, listing Cummins among those "willing to compromise under conditions." These senators, though not so promising as those found to be "urgent for settlement" or "also desirous of compromise," were nevertheless worthy of cultivation, Hitchcock thought. ${ }^{37}$

Some senators engaged in negotiations across party lines. Ignoring this effort, Lodge, on December 20, abruptly pushed through the Foreign Relations Committee a resolution authored by Senator Philander Knox calling for a separate peace..$^{38}$ Senator Frank Kellogg immediately told the press that the mild reservationists had not been consulted and would not support the resolution until shown that ratification with reservations was not possible. ${ }^{39} \mathrm{~A}$ flurry of conferences ensued, culminating in a meeting on the morning of December 21 in which Cummins participated, along with mild reservationists Kellogg, McNary, Colt, Edge, and Hale. Cummins joined the others in agreeing to notify Lodge of their strong opposition to the Knox resolution and their desire for compromise and prompt treaty approval. The group called on Lodge at his home and impressed on him their insistence that he treat with Democratic leaders; they also offered specific suggestions. Lodge agreed to the desirability of ratification with proper reservations in order to keep the issue out of the campaign, and

37. Hitchcock to Wilson, 24 November 1919, Woodrow Wilson Papers, Library of Congress.

38. Thomas A. Bailey, Woodrow Wilson and the Great Betrayal (New York, 1945), 403; U.S. Senate, Proceedings of the Committee on Foreign Relations, 66th Cong., 1st sess., 20 December 1919, 211-12.

39. New York Times, 21 December 1919. 
also agreed to some concessions to the Democrats, especially on the preamble. ${ }^{40}$

In light of the hard line Cummins had taken during the October and November voting, his actions in December seem puzzling. His motives are a matter for speculation, but if he remained concerned with clearing the deck for Senate consideration of vital domestic questions, including the Esch-Cummins Bill, then his actions are understandable. The Knox resolution for a separate peace, against which he reacted, would not accomplish the purpose, for it faced a certain presidential veto that could not be overridden. It was, then, a purely political gesture. Only ratification could free Congress from the treaty issue. That Cummins's Iowa colleague William Kenyon was active in compromise discussions with Democrats, and that in the country at large there was much demand for some form of ratification, may also have influenced the senator. In addition, he still had personal political reasons to want to be rid of the issue before the 1920 election.

A bipartisan conference headed by Lodge and Hitchcock met for two weeks at the end of January. Although certain tentative agreements were reached, the conferees failed to achieve an overall agreement. Yet public demand for action persisted, so Lodge brought the treaty before the Senate in February for fresh consideration of reservations and ultimately for another ratification vote. In the Senate's new deliberations, Cummins took a hard line on Article Ten and military obligation, as he had done consistently. Early on, he declared his opposition to any change in the reservation to Article Ten, as did thirteen other Republican senators drawn from the ranks of strong reservationists and moderates. ${ }^{41}$

Yet supporters of the covenant still thought Cummins might yield to pressure to compromise. When William Short, secretary of the powerful pro-League lobby, the League to Enforce Peace (LEP), met with mild reservationist leaders McNary, Kellogg, and Lenroot in early February, they gave him a detailed review of

40. Portland Oregonian, 23 December 1919; Charles McNary to William Howard Taft, 22 December 1919. Taft Papers; Alice Roosevelt Longworth, Crowded Hours (New York, 1933), 294-95.

41. The World (New York), 13 February 1920; New York Times, 15 February 1920. 
the situation. Short reported back to William Howard Taft, president of the LEP, that there was "a new group of mild reservationists" who might, under pressure, yield more to the Democrats. Cummins was named as part of the group. ${ }^{42}$

Cummins showed his strong concern for ratification when, on March 4, he joined seven other Republicans in a temporary break with Lodge. The Republican leader had supported new reservations agreed to at the bipartisan conference, but when Hitchcock refused to back one of these, relating to American representation on commissions, Lodge angrily offered the November 19 formulation instead. Democrat Tom Walsh of Montana, a member of the bipartisan conference, offered the conference's compromise as a substitute, and with the help of Cummins and his seven Republican colleagues, it passed, $37-32 .{ }^{43}$ Thereafter, Lodge became more tractable.

On March 18, as the Senate completed action on reservations, Senator James Reed of Missouri offered an important reservation to exempt matters of national honor and interest from pacific settlement procedures. Cummins opposed the measure, as he had in November. And as before, the reservation was defeated. Moments later, Cummins supported Reed's proposal that the United States renounce military obligation under any article of the treaty. The reservation lost, 16-57.44

Chances for ratification had dimmed when President $W$ ilson made clear his preference for a "solemn referendum" on the League in the election of 1920, as against significant concessions to Republican reservationists. Political advantage thus became even more important. In that context, Peter Gerry, a Rhode Island Democrat, offered a new reservation that urged self-government for the Irish and then prompt admission of Ireland to the League. If adopted and made part of the ratification resolution, it would have been difficult for Great Britain to accept it. After extended and heated debate, the Senate approved the reservation, 38-36. Republicans divided, eighteen for, twenty against. Cummins was among those who opposed the reservation. Some other

42. "Report of W. H. Short on Treaty Situation ... . in Short to William Howard Taft, 10 January 1920, Taft Papers.

43. $C R$ 66:2, 3857-62, 4 March 1920.

44. Ibid., 4497, 4498, 18 March 1920. 
moderates, and even a few mild reservationists, voted for the politically attractive motion. Earlier, Cummins had been part of a 28-51 minority in voting to table the motion. ${ }^{45}$

The following day, March 19, the Senate took up the perfected resolution of ratification. After some heated debate, the vote on the resolution fell seven votes shy of a two-thirds majority, 49-35. Loyalist Wilson Democrats voted with irreconcilables against Lodge's resolution. ${ }^{46}$ Although debate on the League persisted in the months that followed, it was never again formally considered in the Senate.

TWO WEEKS BEFORE THE FINAL SENATE VOTE, Cummins confided his views to former Senator Albert J. Beveridge of Indiana, a colleague in the days of insurgency and now a leading irreconcilable. "While I do not fully agree with you," he wrote, "our differences are very slight as compared to our concurrences." Cummins believed that "a council of nations, without substantial power, meeting regularly to discuss the affairs of the world could exercise a mighty influence in preventing war." But he did not praise the rest of the pacific settlement portion of the covenant, perhaps because of the enforcement provisions of Article Sixteen. Nor did he endorse even the negative guarantee of Article Ten, by which members renounced military aggression against one another ${ }^{47}$ Cummins seemed ready to approve those provisions of the covenant that allowed for peaceful settlement of disputes through adjudication or arbitration, but he was opposed to a universalism that would invite American involvement in police-type actions for preserving the peace. These views were not unique to Cummins or even to the moderates. With some variations, they were shared by most of the senators who insisted on reservations.

Despite his rather conservative views, reflected especially in his voting on all matters relating to the use of force, Cummins occasionally had been active for treaty approval in the course of the prolonged battle. He advanced the cause of compromise in July and August when he joined mild reservationists in formulating a

45. Ibid., 4511, 4522, 18 March 1920.

46. Ibid., 4599, 19 March 1920.

47. Cummins to Beveridge, 6 March 1920, Albert J. Beveridge Papers, Library of Congress. 
reservationist program, and he did so again in helping to pressure Lodge to compromise in December. In some of his votes, as on the Reed reservation, the Fall amendments, the Shantung amendment, and the Gerry reservation, he also served the cause of ratification and American entry into the League. By these actions he separated himself from the irreconcilables and strong reservationists, though by other actions he kept his independence from the mild reservationists. With some others, he carved out for himself the intermediate position of a moderate.

Cummins was more favorable to the League and the treaty than were strong reservationists such as James Wadsworth of New York or Joseph Frelinghuysen of New Jersey not because he was more of an internationalist than they. Rather, he felt greater urgency about being done with the issue to make way for other legislation and for other reasons. Even some of the more conservative of the mild reservationists, men such as Hale, Edge, and Thomas Sterling of South Dakota, were influenced by similar motives. They had a bit more faith in some aspects of the covenant than Cummins did, but they shared with him a fear of military entanglements and commitments. ${ }^{48}$ Thus, Cummins's very limited internationalism did not automatically align him with the strong reservationists, the category to which he would ordinarily be assigned in the absence of any alternative. It would seem preferable for historians to recognize the existence of a heretofore unrecognized set of senators, the moderates.

48. Margulies, Mild Reservationists, 29-30, 35, 37-38, 56-57, 163, 180, 207, 213. 
Copyright of Annals of Iowa is the property of State of Iowa, by \& through the State Historical Society of Iowa and its content may not be copied or emailed to multiple sites or posted to a listserv without the copyright holder's express written permission. However, users may print, download, or email articles for individual use. 